\title{
Shostakovich and the Peace Conference
}

\section{TERRY KLEFSTAD}

Dmitry Shostakovich's first visit to the United States was an appearance at the Cultural and Scientific Conference for World Peace in New York City in March 1949. He was serving as one of five delegates from the Soviet Union, and as a delegate he listened as his translators read a prepared speech, mumbled brief answers to a few awkward questions, played on the piano once, attended a few concerts, and then left with cartons of cigarettes under his arm. The conference was described in the popular press as pro-Communist propaganda, and protestors picketed the streets outside the Waldorf. Many Americans, however, were familiar with Shostakovich's music, and many knew about the recent banning of his works in the Soviet Union. The popularity of his music in the United States meant that Shostakovich did not receive the same disparaging treatment by his public as did the other cultural delegates. Indeed, the American audience, both in the conference and on the streets, showed him a great deal of sympathy and support. Shostakovich's visit to the United States as a Soviet delegate to the Waldorf Conference is a case study in the often contradictory public messages sent during the early years of the Cold War, and the vital role of music, even when not very present, in cross-cultural exchange.

The Waldorf Conference consisted of a series of speeches by cultural, scientific, and artistic delegates from various nations. It was an extended dialogue. There were no literary readings, dramatic performances, or concerts (those attended by Shostakovich were not part of the conference). The panels began on Friday, March 25, with a dinner and short speeches by chief delegates, including Shostakovich. Saturday and Sunday morning were reserved for panel and plenary sessions, and the conference closed on Sunday, March 27, with a rally in Madison Square Garden. Shostakovich gave a short speech on Friday night, a longer speech at the Fine Arts Panel on Saturday, and late Sunday night played the second movement of his Fifth Symphony on the piano. ${ }^{1}$ This brief performance, coming at the very end of the conference, was the only time music was heard as part of official conference activities. The only other artistic element was an enormous mural by William Gropper that served as a backdrop in the Waldorfs Grand Ballroom. ${ }^{2}$ The speeches given at the conference were published by the conference organizers, the National Council of the Arts, Sciences, and Professions, in a monograph entitled Speaking of Peace. ${ }^{3}$ This document includes transcriptions of the question-and-answer sessions that followed and sometimes preceded the panels.

The panels were, as the conference's title suggests, cultural and scientific: Natural Science, Physical and Mental Health, Planning and Building, Economic and Social Sciences, Writing and Publishing, Fine Arts, Mass Communications, Education, and Religion and Ethics. ${ }^{4}$ General themes in the speeches

\footnotetext{
1 “Global Unity Call, Cheered by 18,000, Ends Peace Rally," New York Times, March 28, 1949. There is some discrepancy in program drafts in archival documents. The typed draft shows the Fine Arts Panel (Shostakovich's longer speech) as planned for Saturday evening, but a printed brochure lists it as Sunday morning. Press accounts, however, place his long speech on Saturday. Harlow Shapley Archives, Harvard University.

2 "Red Visitors Cause Rumpus," Life 36, no. 14 (April 4, 1949), 41.

${ }^{3}$ Daniel S. Gillmor, ed., Speaking of Peace, (New York: National Council of the Arts, Sciences, and Professions, 1949).

${ }^{4}$ This information and that following is summarized from the conference proceedings, Speaking of Peace. This document seems fairly reliable for general information on the conference, and a close comparison of Shostakovich's speeches therein
} 
included the role of the United Nations, the dangerous nature of NATO (which excluded the U.S.S.R.), criticism of U.S. foreign policy and armament, the nature of democracy, intellectual freedom, and the general climate of fear. Most of the speakers advocated a strong government hand in building a new society and the need for centralized control, not only within nations but also among nations. These ideas seem redolent of communism, but also eerily familiar in twenty-first century America. For example, speakers on the health panel called for a national health system and a move away from the fee-for-service structure. ${ }^{5}$ Overall, the tone of the conference seemed to advocate a respect for individual freedom but also a strong desire for governments to take action for the common good.

\section{Peace and Politics}

The Waldorf Conference took place during the rising years of the Cold War. Two superpowers, the United States and the Soviet Union, were emerging, and there was considerable tension between them. The past twenty years or so had been a time of instability in relations between the nations, as American intellectuals saw the Soviet experiment as a possible utopia and then became disillusioned as news of the Stalinist purges slowly made its way to the United States. ${ }^{6}$ The U.S. government was reluctant to recognize the Bolsheviks and their new government and only gave diplomatic recognition to the newly formed Soviet Union in 1933, sixteen years after the revolution. Cultural exchange was alternately encouraged and discouraged by writers in the American press, who reflected the curiosity and ambivalence of American intellectuals. World War II brought more uncertainty, as the non-aggression pact with Hitler in August 1939 made the Soviet Union an official wartime adversary of the United States, and then an ally again in June 1941 when Hitler broke the pact and invaded Russia. By 1949, the most pressing issues were fears of the atomic bomb, consternation over foreign policy issues, and the continuing aftermath of World War II. At the time of the Waldorf Conference, the Berlin airlift was in its last months, and the Soviet Union had not yet developed its own atomic bomb. ${ }^{7}$

The Soviet delegates to the peace conference were cultural, as befitted the stated aims of the conference: Shostakovich, Alexander Fadeyev (author of The Young Guard, the novel behind the film to which Shostakovich had recently composed the music), Sergey Gerasimov (film director), Alexander Oparin (biologist), Pyotr Pavlenko (novelist and film writer, including the script for Alexander Nevsky), Mikhail Chiaureli (film director and producer), and Ivan Pozharsky (interpreter and secretary). For the Soviet delegates in particular, promoting the ideal of world peace was directly in line with Soviet government policy. The Soviet strategy from the early 1940s was to portray their own nation as peaceful and other nations as aggressive. ${ }^{8}$ This attitude was prevalent in their speeches, which ostensibly promoted

and in Sovetskaya Musïka ("V zashchitu mira i kulturï," May 5, 1949, 8-14) and Music Notes ("Formalism vs, Realism in Music," May 1949, 3, 4, 19) suggests that the speeches are accurate as well. Minutes in the Shapley archives mention that tape recordings of all the speeches were made, with the implication that Speaking of Peace was transcribed from them.

${ }^{5}$ Gillmor, Speaking of Peace, 48.

${ }^{6}$ See Terry Klefstad, “The American Reception of Dmitri Shostakovich 1928-1946” (Ph.D. diss., University of Texas at Austin, 2003), chap. 1.

${ }^{7}$ John Lewis Gaddis elaborates on these issues in A Cold War: A New History (New York: Penguin Press, 2005). See also Gaddis, "Nuclear Weapons and the Early Cold War," chap. 4 in We Now Know: Rethinking Cold War History (Oxford: Clarendon Press, 1998); Paul Boyer, By the Bomb's Early Light, (Chapel Hill: University of North Carolina Press, 1994); and Boyer, Promises to Keep: The United States Since World War II (New York: Houghton Mifflin, 1999).

${ }^{8}$ Alvin Rubinstein, Soviet Foreign Policy Since World War II (Boston: Little, Brown, and Company, 1981), 269-71. See also Joseph Nogee and Robert Donaldson, Soviet Foreign Policy Since World War II (New York: Pergamon Press, 1981), 78-80; and Adam Ulam, The Rivals: America and Russia Since World War II (New York: Penguin Books, 1971), 109. 
peaceful international relations but were replete with words like "struggle." Throughout the conference, polite words were spoken, and some mild debate took place during a tense time.

\section{The Conference and the Peace Movement}

The Cultural and Scientific Conference for World Peace was only one of a number of peace conferences and rallies in the late 1940s, culminating in the Stockholm Peace Petition in 1950, which eventually received over a million U.S. signatures in protest of atomic warfare. ${ }^{9}$ The Waldorf Conference, however, was different from the other peace conferences; it was conceived of and sponsored by American civilians, and it had no direct or obvious connection to the Soviet Union in terms of planning, organizing, or sponsorship. Shostakovich's role at the Waldorf Conference, therefore, was as a delegate sent by his government to participate in an American conference. The popular press in the United States was unaware of this distinction and treated the Waldorf Conference as just another one of the many peace conferences that were indeed associated with Communist Front organizations.

During the 1940s the peace movement in the United States had gradually become associated with the communist cause, and "peace" had become a metaphor for communism. The peace movement has been analyzed in detail by Robbie Lieberman in The Strangest Dream. ${ }^{10}$ One can also find an account of some aspects of the peace movement in two government publications by the House Un-American Affairs Committee: A Report on the Communist 'Peace' Offensive and Review of the Scientific and Cultural Conference for World Peace. What follows is a brief overview to provide context for the Waldorf Conference.

One of the main problems of the peace movement was the very nature of their cause: to promote peace, international cooperation was necessary. And international cooperation meant including Soviets in peace talks. Rising cold war sentiment in the mid and late 1940s was not conducive to Americans cooperating with Soviets. Some peace organizations, like the Fellowship of Reconciliation and the American Civil Liberties Union, officially excluded Communists. ${ }^{11}$ But many peace organizations, such as the American Student Union, advocated cooperation between Communists and non-communists, and some, such as the American Youth Congress, gradually became controlled by a Communist majority. ${ }^{12}$ By the late 1940s, the reputation of the American peace movement suffered from two problems: first, the inclusion of and control by Communists; second, a platform that criticized U.S. foreign policy at a time when criticism of one's government was considered subversive. ${ }^{13}$ A report issued by the House UnAmerican Activities Committee in April 1951 explicitly linked the entire peace movement to Communists; indeed, it was entitled A Report on the Communist 'Peace' Offensive. This report accused the peace movement of serving as a cover for Soviet aggression and aiming to develop a false sense of security in the American

\footnotetext{
${ }^{9}$ A cover article in Time warned readers of the deceptive nature of the movement. "Flight of the Dove," Time, September 17, 1951. The U.S. House Un-American Activities Committee gave the petition special attention in its Report on the Communist 'Peace' Offensive, 82nd Congress, First Sess., April 25, 1951, U.S. House Report No. 378. The report reproduces as a foldout an advertisement from The Worker, June 11, 1950, asking for "five million signatures to ban atom war."

${ }^{10}$ The Strangest Dream: Communism, Anticommunism, and the U.S. Peace Movement, 1945-1963 (Syracuse: Syracuse University Press, 2000).

${ }^{11}$ Ibid., 24.

12 Ibid., 25.

${ }^{13}$ Ibid., 8.
} 
people. Four pages of this document are devoted to a discussion of the Waldorf Conference. ${ }^{14}$ By the time of the Waldorf Conference, the peace movement had begun to disintegrate.

The Henry Wallace campaign in 1948, according to Lieberman, had "cinched the link between peace and communism." ${ }^{15}$ Wallace ran under a platform of peace and separate spheres of influence (the United States and the Soviet Union). During the course of his campaign, his Progressive Party became associated with the Communist Party, thanks to their support of his candidacy. After his defeat, his name became, accurately or not, synonymous with Communist cooperation. Wallace was one of the panel speakers at the Waldorf conference, and the founding documents of the National Council of the Arts, Sciences and Professions, which organized the conference, explicitly expressed support for Wallace's campaign. ${ }^{16}$

During Wallace's campaign, in August 1948, Polish Communists sponsored the World Congress of Intellectuals for Peace in Wroclaw (Breslau, Poland). Although non-communist delegates attended the conference, the general tone of the event was reportedly anti-American and pro-Soviet, according to the HUAC Report. ${ }^{17}$ Alexander Fadeyev, Soviet novelist, was one of the main speakers at Wroclaw, and he had harsh words for American writers. He called them “'jackals' who 'learned to use the typewriter' and 'hyenas' who 'mastered the fountain pen'” and accused them of conspiring to provoke war, according to the Report. ${ }^{18}$ Many Americans attended the meeting, including some who would also speak at the Waldorf Conference: Howard Fast, Harlow Shapley (organizer of the Waldorf Conference), Saul Carson, Clifford Durr, O. John Roggee, and Colston E. Warre. ${ }^{19}$

The Cultural and Scientific Conference for World Peace at the Waldorf in March 1949 was the next major international conference, and with the overlap of participants, it is no wonder that that the American press (and government documents) depicted it as yet another front for Communist propaganda. Another conference, the World Congress of Partisans for Peace in Paris, quickly followed on its heels in April 1949. The Paris Congress was more directly associated, even in the HUAC Report, with Cominform, an international communist movement that was dominated by the USSR. Ilya Ehrenburg, Soviet journalist and writer, was present at the Wroclaw and Paris Congresses but not at the Waldorf Conference. A study of the peace movement by Donald McLachlan in 1951 completely ignores the Waldorf Conference and focuses on Wroclaw, Paris, and later congresses. ${ }^{20}$ Although these sources indicate that the Wroclaw and Paris congresses were directly connected to, and may have been organized by, the Cominform, the force behind the Waldorf Conference was not connected to the Communist Party.

The sponsoring body of the Waldorf Conference, the National Council of Arts, Sciences and Professions, was a group of American progressives and intellectuals whose concerns were labor, civil rights and liberties, foreign policy, and world peace. ${ }^{21}$ Harlow Shapley, one of its founders, insisted that the NCASP was an independent organization, independent even of the Progressive Party. ${ }^{22}$ The Council did

\footnotetext{
${ }^{14}$ Report, 12-15.

${ }^{15}$ Lieberman, Strangest Dream, 32.

${ }^{16}$ National Arts, Sciences and Professions Council Policy and Program for 1948, Harlow Shapley Archives.

${ }^{17}$ A discussion of this conference begins on page 8 of the HUAC Report. An analysis of the "Partisans of Peace" movement also describes this conference as anti-American and pro-Soviet. See Donald McLachlan, "The Partisans of Peace," International Affairs 27, no. 1 (January 1951): 10-17.

${ }^{18}$ Report, 8.

${ }^{19}$ This list was compiled by comparing lists of names in the HUAC Report with Speaking of Peace.

${ }^{20}$ McLachlan, "Partisans of Peace."

${ }^{21}$ Lieberman, Strangest Dream, 59.

${ }^{22}$ Minutes of the National Board of Directors of the NCASP, March 26, 1949, Harlow Shapley Archives.
} 
not send an official observer to the Paris Conference. ${ }^{23}$ Further, a letter from Shapley to Dorothy Fisher speaks of the problems of supporting a movement so often associated with communism: "Even so it is possible that those who seek malice can find some, and anyone who joins [the telegram of greetings to Soviet delegates] may be charged as a pro-Soviet sympathizer." ${ }^{24}$ Another letter from Shapley to the Dean Acheson, Secretary of State, said: "Our conference is not related in any way whatever to conferences that have been held elsewhere or that are being planned." The same letter notes that the conference was planned primarily for Americans, but that a small number of foreign delegates was invited. ${ }^{25}$

The Waldorf Conference placed a high priority on artistic and intellectual freedom, even to the point of allowing dissenters to speak freely. Norman Cousins, who opposed many of the viewpoints expressed at the conference, was allowed to speak, albeit to boos and hisses from the audience. Throughout the proceedings, Shapley reiterated that this conference would be free and open, and indeed some of the speeches even criticized the Soviet Union. ${ }^{26}$ Lieberman offers an extensive discussion of this issue and cites interviews with Fast and documents written by Shapley as evidence that the Waldorf Conference was intended to be a "nonpartisan conference" and that it focused on cooperation rather than vilifying the U.S. $^{27}$

The conference was organized and sponsored primarily by Americans, and this makes it different from the other peace congresses. In my own reading of the founding documents and minutes of the NCASP, Harlow Shapley appears to be an intellectual idealist who valued intellectual freedom as much as world peace. According to Shapley, the Soviet Government (not the Council) selected their own delegates to the Waldorf Conference. ${ }^{28}$ A letter from Shapley to Patrick Blackett dated February 18, 1949, mentions that Shapley received a letter from the Soviet ambassador in Washington stating that the Soviet government was selecting its own delegates. He expresses concern over the reaction of the United States government, but then dismisses it. His comment on Fadeyev refers to strong anti-American sentiments expressed by the author at the Wroclaw conference:

Not altogether unexpectedly, because of some preliminary premonitions, I received today at my New York office a letter from the Soviet Ambassador in Washington saying that the importance of our Conference is recognized by his Government and his people, or something like that, and that arrangements were being made to bring five of their leading artists, scientists, and professionals to America for that Conference. In a way this bowls us over. . . this coming of the Russians, at the announcement to me by way of the Ambassador in Washington, suddenly gives our Conference a high significance. I cannot believe that Fadeev [sic] will mess things up the way he did in Poland. Of course much of our press, and some of our Government, will look on this whole matter as peace "offensive," or some political trick. But the hell with them! ${ }^{29}$

\footnotetext{
${ }^{23}$ Minutes of the National Executive Committee of the NCASP, April 6, 1949, Harlow Shapley Archives.

${ }^{24}$ Letter to Dorothy Fisher, March 10, 1949, Harlow Shapley Archives.

${ }^{25}$ Letter from Harlow Shapley to Dean Acheson, February 8, 1949, Harlow Shapley Archives.

${ }^{26}$ For example, O. John Rogge said, "In the Soviet Union there is not sufficient freedom for political minorities." Gillmor, Speaking of Peace, 25. Aaron Copland said, "The Soviet Union is impoverishing itself in the cultural sphere by not encouraging every possible musical exchange with our country" (91).

${ }^{27}$ Lieberman, Strangest Dream, 59-61.

${ }^{28}$ Kenneth Campbell, "Shostakovich in Soviet Delegation to Attend Arts Conference Here," The New York Times, February $21,1941$.

${ }^{29}$ Letter from Harlow Shapley to Professor Patrick M. S. Blackett, University of Manchester, England, February 18, 1949, Harlow Shapley Archives.
} 
From this letter, it seems that neither Shapley nor the NCASP selected the Soviet delegates, but rather that they were sent by the Soviet government. This is another indication that the Waldorf Conference had little to no connection to Communist-sponsored front activities; it is almost as though the delegates were sent in order to ensure that the Soviet Union had a seat at the international conference.

The difference in the Waldorf Conference also shows up in the U.S. House Un-American Activities Committee's (HUAC) published documents that discuss this conference: Review of the Scientific and Cultural Conference for World Peace (April 19, 1949) and Report on the Communist 'Peace' Offensive (April 25, 1951). These documents show a strong anti-Soviet bias. The Report links the Wroclaw and Paris Congresses directly to the Cominform. It cites Cominform publications that mention Wroclaw and Paris, and it cites a speech by M. Suslov at the Third Cominform Congress (November 1949) that lists the Paris, Budapest, and Wroclaw Congresses, but not the Waldorf Conference. The Report's discussion of the Wroclaw and Paris Congresses cites reports in the Soviet media (Moscow New Times, Soviet Literature), while its discussion of the Waldorf Conference focuses primarily on speeches given. Cited external reports and references to the Waldorf Conference use phrases like "real leaders of America" and "the voice of truly progressive, noble America." ${ }^{30}$ In other words, the language of the HUAC Report seemed to focus on the American-ness of the Waldorf Conference and the foreign influence of the Wroclaw and Paris Congresses. Although the Review makes more explicit connections between the Wroclaw and New York events (calling the Waldorf Conference a follow-up to the Wroclaw), even that extensive document focuses mainly on the nature of the National Council of the Arts, Sciences, and Professions as a front group for the Communist Party. The conference was referred to as a "sounding board for Communist propaganda," but is not once in this document connected directly to the Comintern. ${ }^{31}$ Outside of the Report and Review, there is even a difference in vocabulary: Wroclaw and Paris are "congresses," and New York is a "conference."

The published conference proceedings, titled Speaking of Peace, include a statement from Harlow Shapley that ends with this:

The Conference was for world peace, not for unilateral and bilateral ill-will. It sought to promote the necessary understanding and goodwill among men, not to incite further the atmosphere of distrust between them. ${ }^{32}$

According to the document, over 2,800 people registered to attend the conference, and hundreds had to be turned away. ${ }^{33}$ In addition, over 500 people signed on as sponsors of the conference, lending their support to the cause of peace. A list of sponsors appears in the Shapley Archives and in the HUAC Review. Sponsors from the musical world included George Antheil, Leonard Bernstein, Aaron Copland (also a panel speaker), Lukas Foss, Morton Gould, Roy Harris, Alan Lomax, Arthur Schnabel, and Nicolas Slonimsky. The sponsors agreed to add their names long before the conference, and several (not those above) withdrew their support when the popular media began to portray the conference as communist propaganda. To add to the confusion, some that the media reported as having withdrawn their support had not done so. ${ }^{34}$

\footnotetext{
${ }^{30}$ Report, 15.

${ }^{31}$ Review of the Scientific and Cultural Conference for World Peace, 81st Congress, 2nd sess., April 19, 1949, House Report No. 1954, 11.

${ }^{32}$ Gillmor, Speaking of Peace, viii.

${ }^{33}$ Ibid., v. The New York Herald Tribune reported 2,000 in attendance at the opening dinner. "Seven Russian Guests," March 27, 1949.

34 "Police Lift All Restrictions On Culture Meeting Pickets," New York Times, March 25, 1949.
} 


\section{Shostakovich and the United States, and How He Got to the Conference}

By 1949, Dmitry Shostakovich was a household name in the United States. His First and Fifth Symphonies were part of the established American symphonic repertoire, and his war symphonies-the Seventh, Eighth, and Ninth—had been greatly anticipated and then received with enthusiasm by American audiences. ${ }^{35}$ The American premieres of the symphonies had followed their Soviet premieres closely, and the response to them was fairly consistent: the audiences loved the works, while the critics expressed disapproval for many aspects, especially their ungainly length, Shostakovich's habit of borrowing ideas from other composers, and from the Fifth on, their overt connections to the Soviet policy of socialist realism. Americans saw the opera Lady Macbeth of Mtsensk District in 1935, a full year before the famous "Chaos Instead of Music" article in Pravda criticized the work as formalist (and thus anti-Soviet). ${ }^{36}$ American critics gave the opera a great deal of attention. They speculated on the opera's propagandistic nature (having read in Modern Music that Shostakovich intended it as anti-bourgeois commentary) and expressed prurient interest in the opera's sexually charged plot. ${ }^{37}$ When word reached the United States of the "Chaos" article and Shostakovich's official disgrace, the same critics had to re-evaluate their reactions to the opera. Lady Macbeth had been received by Americans as anti-bourgeois Soviet propaganda; with the "Chaos" article, they learned that the Soviet government thought the opera to be formalist, leftist, and ideologically wrong. Thus critics and audiences in the United States saw Shostakovich in a new light, as a composer who was responsible to his government for his choice of musical style. His political and artistic persecution made him, if anything, a more sympathetic figure for Americans.

The work that marked the peak of Shostakovich's popularity in the United States was the Seventh Symphony, "Leningrad," which came to America in 1942. ${ }^{38}$ The United States and the Soviet Union were allies at the time of its first performances in America, and the symphony was principally received as a programmatic statement of solidarity against fascism. The Seventh received an enormous amount of advance publicity, and the conductors Artur Toscanini, Sergey Koussevitsky, and Leopold Stokowsky vied for first performance rights. Toscanini received the honor of the first (broadcast) performance, and Koussevitzky the first concert performance. ${ }^{39}$ As a war symphony, it was later even performed for U.S. troops in California, and the critic remarked: "By now it is almost unpatriotic not to like Dmitri Shostakovich's Seventh Symphony." ${ }^{40}$ His Eighth Symphony was also widely performed in America, and though Shostakovich himself gave no hint of a specific wartime program, it was widely seen as a sequel to the Seventh; some called it "the Military." ${ }^{11}$ The music critic for the New York Post, Harriet Johnson, called the Eighth "an impressive musical document of the Russian people's thoughts and feelings during the

\footnotetext{
${ }^{35}$ By 1949, Americans had heard the First, Third, and Fifth through Ninth Symphonies as well as the opera Lady Macbeth of Mtsensk District. For a thorough treatment of the rise of Shostakovich's reputation in America, see Klefstad, "Reception."

${ }^{36}$ Translated into English and reprinted as "Chaos Instead of Music" in International Literature (1936): 77-79), this originally appeared in Pravda on January 28, 1936.

${ }^{37}$ Shostakovich, "My opera, Lady Macbeth of Mtsensk," Modern Music 12, no. 1 (1934): 23-30.

${ }^{38}$ Klefstad, "Reception," 42. Also see the repertoire study by Kate Hevner Mueller, Twenty-Seven Major American Symphony Orchestras: A History and Analysis of their Repertoire, Seasons 1842-43 through 1969-70 (Bloomington, Indiana University Press, 1973), xxxii.

${ }^{39}$ Klefstad, "Reception," 200-04. For letters exchanged between Toscanini and Stokowsky, see Oliver Daniel, Stokowski: A Counterpoint of View (New York: Dodd, Mead, and Company, 1982), 454-57.

40 "Shostakovich's Seventh: The Russian Composer's Newest Symphony has Become a Symbol of the Soviet's Brave Fight,"

Life 13 (November 9, 1942): 99-100.

${ }^{41}$ Klefstad, "Reception,” 241.
} 
war." ${ }^{42}$ Both the Seven and Eighth symphonies were perceived by some in the American press to be Soviet war propaganda, and American audiences responded with enthusiasm when they were performed. They expected the next symphony to be the completion of a war trilogy. In 1946, however, Shostakovich surprised everyone with his Ninth Symphony, a short, humorous, Haydnesque essay in neoclassicism. The Ninth did not receive nearly the press attention in America that the Seventh and Eighth had received.

American audiences were also aware, thanks to articles in the popular press, of Shostakovich's troubles with his government. They read about the troubles that the composer experienced in 1946, when word of a critical article by Izrail Nestyev about the Ninth arrived in the U.S. via descriptions in the New York Times, Newsweek, and Time. Americans were somewhat bewildered, as the Ninth had been received positively in the States. Significantly, Americans were reminded of the difficulties of Shostakovich's position as a Soviet artist who was accountable to government officials for his choice of musical style. ${ }^{43}$ With the Soviet criticism of the Ninth, one sees the acceleration of a growing sympathy in the United States for Shostakovich as an artist that would color Americans' understanding of the 1949 peace conference in New York. For example, Olin Downes wrote of Shostakovich's need for artistic independence from official supervision. ${ }^{44}$ The 1946 attacks on Shostakovich's Ninth Symphony, however, would soon be overshadowed by the 1948 resolution issued by the Central Committee accusing Shostakovich and five other composers of bourgeois formalism in their music. ${ }^{45}$

The trouble began with two Soviet conferences held in January 1948 of composers and others from the musical world. The second conference, which began on January 10, concerned Vano Ilyich Muradeli's opera, The Great Friendship. The discussion quickly became a time of careful examination of the Soviet musical world for evidence of bourgeois formalism. Shostakovich in particular suffered a great deal of criticism, especially for his Eighth and Ninth Symphonies. ${ }^{46}$ On February 10, 1948, the Central Committee issued a resolution, ostensibly about Muradeli's opera, but including accusations that many Soviet composers had moved in a formalist direction (Shostakovich, Prokofiev, Khachaturyan, Shebalin, Popov, and Myaskovsky were named). Formalism, being considered "alien to the Soviet people and its artistic tastes," was a serious accusation with serious consequences. ${ }^{47}$ From February 17 to 26, a conference of composers and music scholars in Moscow provided a forum for additional criticism of the accused composers and a chance for them to offer their apologies and regrets. Shostakovich gave a speech; Prokofiev sent a letter. ${ }^{48}$ Shostakovich's speech was similar in tones to parts of the speech he would deliver a year later at the 1949 Waldorf Conference; he admitted his failure and pledged to try to compose music that appealed to the Russian people. ${ }^{49}$

\footnotetext{
${ }^{42}$ Harriet Johnson, “The Shostakovich Eighth Expresses Vital Ideas with Emotional Power,” New York Post, April 3, 1944. Courtesy of the New York Philharmonic Archives.

${ }^{43}$ Klefstad, "Reception," 298-99.

${ }^{44}$ Olin Downes, "Politics vs. Art: Ninth of Shostakovich Raises Question Anew," New York Times, November 17, 1946. For a later example of similar sentiments, see Irving Kolodin, "The Ninth of Shostakovich,” New York Sun, November 2, 1964.

${ }^{45}$ Formalism is a difficult and problematic term, and it is almost always discussed in opposition to realism, more commonly known as "socialist realism." Essentially, formalist music focuses more on the processes and structures of music (in an abstract sense) than on its content, or program. Shostakovich addressed this issue directly in his speech, which is examined later in this essay.

${ }^{46}$ For a published summary in English of much of the dialogue at the conference, see Alexander Werth, Musical Uproar in Moscow (Westport, Connecticut: Greenwood Press, 1973), esp. pages 54 and 71. This conference is also discussed in Laurel Fay, Shostakovich: A Life (Oxford: Oxford University Press, 2000), 156.

${ }^{47}$ Fay, Shostakovich: A Life, 158.

${ }^{48}$ These are both reproduced in Laura Kuhn and Nicholas Slonimsky, eds., Music Since 1900 (New York: Schirmer Reference, 2001), 948-51.

${ }^{49}$ See also Fay, Shostakovich: A Life, 160.
} 
News of these events reached the U.S. immediately, with reports in the New York Times on February 12 and 15. An editorial in the March 1948 issue of The Musician called the events censorship and decried the suppression of individual rights. Alexander Werth described the events in a series called "Russia, Plus and Minus" in The Nation, and in December the New York Times Magazine placed the Soviet music conference in the context of a larger discussion of Soviet attacks on artists and intellectuals of all fields. ${ }^{50}$

The results of this public reprobation were harsh for Shostakovich. Many of his works were banned from performance in the Soviet Union, and he lost his positions at the Moscow and Leningrad Conservatories. Laurel Fay writes that during this time "there were indications that he considered suicide," and that his housekeeper spent her own savings to feed his family. ${ }^{51}$ In many ways, the effects of this criticism on Shostakovich's career were more severe than the 1936 attack on Lady Macbeth of Mtsensk District. In 1936, no official ban on his works was issued, and he was still a young and rising composer. In 1948, Shostakovich was expelled from his teaching positions at both the Moscow and Leningrad Conservatories, and most of his compositions were banned from performance. By this time, Shostakovich was famous throughout the Western world, and he was well established in the United States as an important Soviet composer. Americans were interested in the political implications of these attacks and addressed the issue in terms of censorship and Soviet inscrutability. Shostakovich's slow return to favor was also tracked in the American press. In October, Time Magazine reported that Shostakovich was reading positive reviews of his music to the film The Young Guard. ${ }^{52}$

Shostakovich was thus in a condition of great personal disgrace and likely depression when he received a personal phone call from Stalin asking him to serve as a delegate to the Cultural and Scientific Conference for World Peace at the Waldorf-Astoria Hotel in New York City. The story of this phone call, which happened in mid to late February 1949, is a favorite in Shostakovich lore, and it appears in English in Shostakovich: A Life (172), Shostakovich: A Life Remembered (212-13), and Testimony (147-48). ${ }^{53}$ Shostakovich bravely offered to Stalin two reasons for not attending the conference: ill health and the banning of his works in the Soviet Union. The composer asked how he could represent Soviet music when his own symphonies were forbidden in the Soviet Union. Stalin asked who had instituted the ban and assured Shostakovich that it would be revoked. On March 16 Shostakovich received a copy of an order withdrawing the ban on his works and those of others that had been issued on February 14, 1948. Stalin also sent doctors to Shostakovich's apartment for an examination, and he was pronounced healthy enough for travel.

Thus did Shostakovich become an official Soviet delegate for the Waldorf Conference. Surely he felt that he was on shaky ground, and it is no wonder that his characteristic nervousness was even more pronounced in New York, as several descriptions of the conference attest. As a delegate, he sat on panels and listened to heated debates on artistic and intellectual freedom (the topic of the Writers' Panel and an

\footnotetext{
50 "Communists Censor Art," The Musician 53, no. 3 (March 1948): 19-20; Alexander Werth, "Russia, Plus and Minus; IV. The Dilemma of Soviet Artists," The Nation 167, no. 8 (August 21, 1948): 207-09; “Soviet Denounces its 'Big 3' in Music, Orders a New Line," New York Times, February 12, 1948.

${ }^{51}$ Fay, Shostakovich: A Life, 164.

52 "Shostakovich Reads the Papers," Time, October 25, 1948, 75. It is well known that during times of personal trouble, Shostakovich turned to the genre of film music to earn money to support his family.

${ }^{53}$ Elizabeth Wilson, Shostakovich: A Life Remembered (Princeton: Princeton University Press, 1994); Solomon Volkov, Testimony: the Memoirs of Dmitri Shostakovich (New York: Limelight Editions, 2004). This book has been discredited as a memoir by a number of scholarly sources; see especially Malcolm Hamrick Brown, A Shostakovich Casebook (Bloomington, Indiana University Press, 2004). The story of Stalin's phone call, though, is fairly consistent with other sources and I would be remiss in not citing Testimony here.
} 
issue addressed frequently throughout the Conference) and apologized for composing in an unapproved style.

\section{Protests and the Media}

The Waldorf Conference received much publicity in the popular media, and the general tone was negative. ${ }^{54}$ The first announcement of the conference appeared on February 21, 1949, in the New York Times, with Shostakovich's name prominent in the title: "Shostakovich in Soviet Delegation to Attend Arts Conference Here." In fact, Shostakovich's name appeared prominently in almost every article on the conference, in both the mainstream and musical press. In a majority of articles that discussed the contents of the conference, Shostakovich's picture appeared. ${ }^{55}$

Controversy over the conference began with an account of protests by the American Legion and the American Jewish League, asking the government to deny visas to Soviet delegates. ${ }^{56}$ Then, the State Department decided to deny visas to various delegates from Great Britain, Italy, and Latin America on the grounds that they were not official representatives of their respective governments. ${ }^{57}$ This move was confusing and evoked much discussion in the American press-why deny visas to some delegates and not to others? ${ }^{58}$ Not all of those denied were even Communists, and none of the British delegates were (J.G. Crowther, Louis Golding, and J.D. Bernal). ${ }^{59}$ The answer (implied by the State Department) seemed to be that there were already enough Communists and pro-Communists coming to the conference. ${ }^{60}$ Shostakovich, of course, was allowed to come along with the other Soviet delegates. They arrived at LaGuardia airport on March 23. Upon their arrival, the Russians gave no interviews, although "Shosty" (this is what the Times called him) waved his hat at the request of reporters (see Figure 1). ${ }^{61}$

During the conference protestors lined up outside the Waldorf. Life Magazine later published pictures of them, as did Time and Newsweek. ${ }^{62}$ Musical America noted that there were about 2,000 protestors at the conference. ${ }^{63}$ However, a media analysis by sociologist Henry Singer later noted that the number of protestors was greatly exaggerated in the American press and that he counted a maximum of thirty-five pickets at any time. ${ }^{64}$ Later, Arthur Miller would write of having to pass between kneeling nuns to enter the hotel. ${ }^{65}$ Most media accounts of the conference included pictures of these picketers. These accounts were undoubtedly influenced by an "action group" run by Sidney Hook, an anti-Communist writer and philosopher, who had rented the bridal suite of the Waldorf and, during the conference, kept many people

\footnotetext{
${ }^{54}$ See Henry A. Singer's word-by-word analysis. "An Analysis of the New York Press Treatment of the Peace Conference at the Waldorf-Astoria," Fournal of Educational Sociology 23, no. 5 (1950): 258-70.

${ }^{55}$ His picture appeared in accounts of the conference in Musical America, Life, Time, Newsweek, and the New York Times. On every day of coverage in the Times, at least one of the articles in each issue had Shostakovich's picture.

56 "Legion Urges U.S. Deny Reds Entry," New York Times, March 16, 1949.

57 "Cultural Visas Denied to British," New York Times, March 22, 1949.

${ }^{58}$ For example, see "Shostakovich Visits America for Turbulent Peace Meeting," Musical America 49 (April 1, 1949): 3; "Red Visitors Cause Rumpus," Life 26, no. 14 (April 4, 1949): 39; and "Seven Russian Guests," New York Herald Tribune, March 27, 1949.

${ }^{59}$ Lieberman, Strangest Dream, 66.

60 "Department Explains," New York Times, March 22, 1949; "New Protest Sent to Acheson On Ban of Cultural Delegates," New York Times, March 23, 1949. See also an editorial read into the Congressional Record "State Department Fiction" source undocumented, 81st Cong., 1st sess., 95, Part 13: A 1825.

61 “7 Russians Silent on Peace Mission,” New York Times, March 24, 1949.

62 "Red Visitors Cause Rumpus"; "Tumult at the Waldorf”; and "Peace: Everybody Wars Over it," April 4, 1949.

63 "Shostakovich Visits America for Turbulent Peace Meeting," Musical America 49 (April 1, 1949): 3-4.

${ }^{64}$ Singer, " Analysis," 264-65.

${ }^{65}$ Arthur Miller, Timebends (New York: Grove Press, 1987), 268.
} 
busy sending out telegrams and press notices critical of the conference. The composer Nicholas Nabokov, a member of the Russian aristocracy who had emigrated from the Soviet Union in the early 1930s and became a U.S. citizen in 1939, was involved with this effort and described it in detail in his memoir, Bagazh. Nabokov wrote that he deliberately tried to expose Shostakovich's impossible position of an artist who cannot speak freely when he asked pointed questions about artistic freedom following Shostakovich's main speech at the Waldorf Conference. He also took part in a counter-conference held immediately after the conference, where he gave a speech lamenting the situation of Soviet composers. ${ }^{66}$

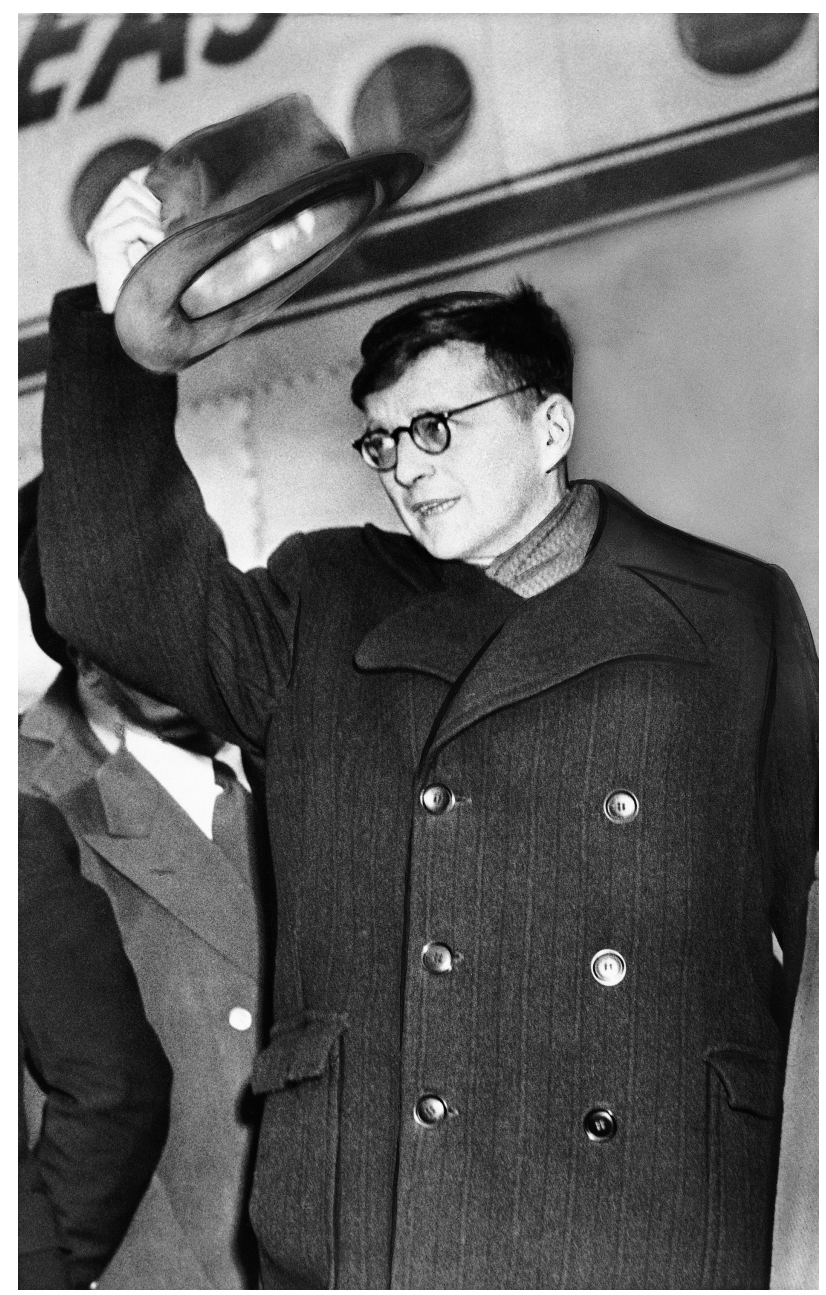

Figure 1. Shostakovich's arrival in New York.

(Associated Press photo; used with permission.)

\footnotetext{
${ }^{66}$ Nicolas Nabokov, Bagazh: Memoirs of a Russian Cosmopolitan (New York: Atheneum, 197), 233-38. Nabokov gives no hint in his memoir that the Central Intelligence Agency funded the counter-conference and Sidney Hook's protest activities in the Waldorf, but Frances Stonor Saunders describes its role in providing funds for this and other anti-communist organizations, many of which Nabokov would later be a part. The Cultural Cold War: The CIA and the World of Arts and Letters (New York: New Press, 1999), 54-55, 93-94ff. Also see an extended study of Nabokov's role in cultural exchange and various music festivals in Ian Wellens, Music on the Frontline: Nicolas Nabokov's Struggle Against Communism and Middlebrow Culture (Hants: Ashgate, 2002).
} 


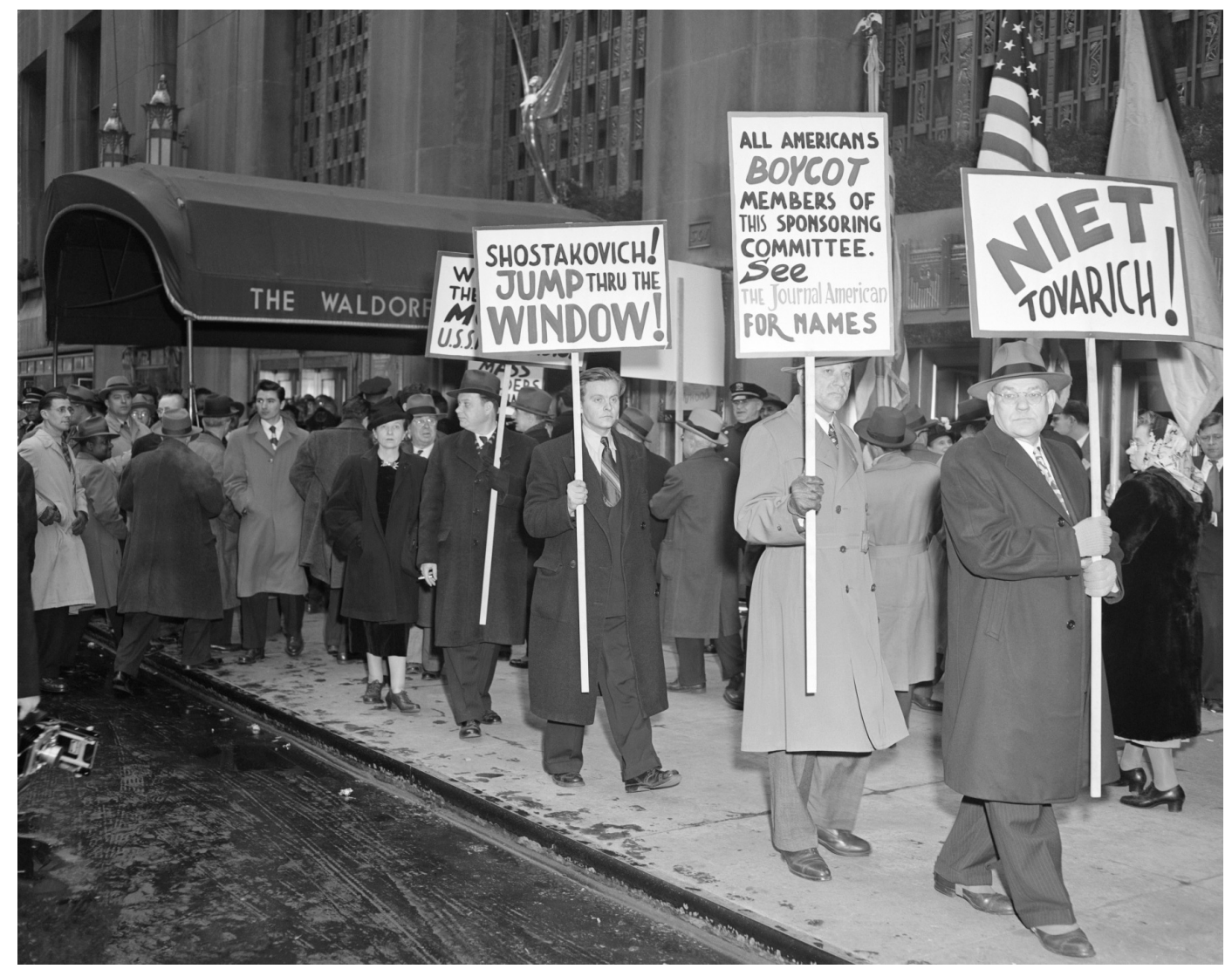

Figure 2. Protestors at the Waldorf Astoria. (Associated Press photo; used with permission.)

Shostakovich's appearance as a Soviet delegate at the Waldorf Conference was received with a great deal of sympathy and not a little skepticism by the American press and observers. Press accounts of his demeanor during this panel session and throughout the conference portrayed a nervous and restless man. ${ }^{67}$ Though protestors held anti-communist signs outside the hotel, and countless articles in the American press denounced the apparently anti-U.S., pro-Soviet slant of most of the conference proceedings, the response to Shostakovich's presence was generally sympathetic. Americans seemed to believe, as Nabokov asserted, that he was not able to respond freely. One demonstrator even held up a sign that advised Shostakovich to "Jump thru the window," a reference to an action recently taken by Oksana Kasenkina, a Soviet woman who defected by jumping out the window of the Russian consulate in 1948 (see Figure 2). ${ }^{68}$ In recent years, Shostakovich had increasingly become a cultural figurehead of the Soviet Union, but ongoing debate in the American press about his treatment by Soviet officials and the popularity of his music with American audiences gave him special status in the eyes of the American public. And Shostakovich's visit to New York City in 1949 gave some Americans the chance to see him up close, and even to express their concern with his perceived plight.

\footnotetext{
67 "Tumult at the Waldorf," Time 53, no. 14 (April 4, 1949): 21-23; "Peace: Everybody Wars Over It,” Newsweek, April 4, 1949, $19-22$; and others.

68 "Red Visitors Cause Rumpus," Life, April 4, 1949, 39.
} 
The American press repeatedly referred to Shostakovich as the star of the show. In lists of delegates, his name always appeared first, and as mentioned above, his picture appeared frequently. ${ }^{69}$ Articles in the New York Times traced the delegates' journey, from the Soviet Union to Berlin, where Fadeyev gave a short interview and Shostakovich said he was too tired to answer questions, to their arrival on March 23 at LaGuardia Airport just before 5:00 p.m. ${ }^{70}$ Even their activities on the plane en route were described (conversations, copious alcohol consumption), revealing an almost tabloid obsession with the Soviet delegates and Shostakovich in particular. The next day, March 24, Shostakovich attended a concert of the New York Philharmonic, conducted by Leopold Stokowski, where Andrzej Panufnik's "Tragic Overture," Virgil Thomson's "Wheat Field at Noon," Jean Sibelius's Concerto for Violin and Orchestra, Opus 47, Aram Khachaturian's “Gayane Suite,” and Johannes Brahms’s Symphony No. 3 were performed.

\section{Speeches}

The conference was given daily coverage by the New York Times. Detailed descriptions of events and the general content of speeches were given in the Times and, after the conference, in Time, Newsweek, and Musical America. In May, Music News published an English translation of Shostakovich's panel lecture, and the above-mentioned periodicals gave fairly detailed summaries of his lecture. More attention was given to Shostakovich's Saturday panel lecture than his Friday night speech. Accounts of the questions by Robert Lowell (following the Writers' Panel) and Nicolas Nabokov (following Shostakovich's Saturday lecture) were also given in the New York Times and Musical America.

Shostakovich even answered a question during the Writers' Panel, which closed with a debate on "Intellectual Freedom in the Soviet Union."71 The issues debated at the end of this panel were relevant to Shostakovich's recent personal experiences-government criticism of an artist's work. W.E.B. DuBois, an author who became closely associated with Communism, opened the Writers' Panel with a speech on "The Nature of Intellectual Freedom." His brief remarks advocated freedom of expression (in both thought and speech) while acknowledging that laws often restrict freedom in attempts to fulfill needs for food, clothing, and shelter. ${ }^{72}$ But the final speech of the panel, by Pyotr Pavlenko, sparked a debate on intellectual freedom. His speech mainly consisted of a celebration of the noble qualities of Russian literature and harsh criticism of "false, spiritually empty, and morally licentious 'propaganda' of war which corrupts millions of readers" in other countries. ${ }^{73}$ Shostakovich was pulled into the debate at the end of this speech.

In response, an audience member, Dwight MacDonald, editor of the magazine Politics, challenged Alexander Fadeyev (the panel chair) on the status of Russian writers-Boris Pasternak, Isaac Babel, Ivan Katayev, Anna Akhmatova, Mikhail Zoshchenko, and Boris Pilnyak-and accused Fadeyev of being "primarily a state functionary." ${ }^{14} \mathrm{He}$ also asked him about official criticism of his novel, The Young Guard.

\footnotetext{
${ }^{69}$ For example, pictures of Shostakovich appeared in feature articles on the conference in Time (April 4), Life (April 4), Musical America (April 1), Newsweek (April 4), and the great majority of articles in The New York Times.

70 "Cultural Visas Denied to British,” March 22; "Have no Instructions from Government," March 23; and "7 Russians Silent on 'Peace' Mission," March 24. Also see articles in the New York Herald-Tribune from March 22 and 23.

${ }^{71}$ Gillmor, Speaking of Peace, 85-87.

${ }^{72}$ Ibid., 78.

${ }^{73}$ Ibid., 84.

${ }^{74}$ In 1946 several Soviet writers, including Anna Akhmatova, had come under attack in the same way that Shostakovich and other major composers would in 1948. Akhmatova suffered official censorship in the 1930s more severe than Shostakovich's Lady Macbeth scandal.
} 
Fadeyev responded by citing recent works by Pasternak (translating Shakespeare into Russian) and Zoshchenko (a 1947 novel). ${ }^{75} \mathrm{He}$ also addressed the ongoing revision of his novel, The Young Guard, stating that he was expanding a section on "the struggle of the adult forces against the Germans." 76 The lively debate continued with discussion by Harvard Professor Francis Otto Matthiessen on the nature of Emerson, Thoreau, and Whitman, and their relations to socialism. The problem of freedom of expression, especially for Soviet artists, was prominent in the minds of those present-it was touched upon repeatedly in speeches and questions.

Robert Lowell, as an audience member, asked two questions during this discussion: one was to Pavlenko regarding his knowledge of the law for conscientious objectors in Russia (Pavlenko replied that he knew nothing about the law and expressed a desire to fight for his country until he is 100 years old, a message somewhat contrary to the pacifist nature of the Conference), and the other directly to Shostakovich: "I wish Mr. Shostakovich would answer, in detail, the effect of that criticism [of the Soviet government] on the integrity of the artist." This was a question directly connected with Shostakovich's reputation and legacy in America; American critics had debated this issue ever since the Lady Macbeth scandal of 1936, when the Soviet government criticized a work that most Americans had thought was Communist propaganda. ${ }^{77}$ Shostakovich responded: "Our musical criticism, reflecting the life and movement of our music, brings me much good, since it helps me to move my music forward." ${ }^{\text {"T }}$ This exchange was also described in Musical America and in the New York Times. ${ }^{79}$ In light of Shostakovich's recent apologies in 1948 to the Central Committee, his ongoing lack of regular employment, and his role as an official Soviet delegate, Shostakovich could give only one answer to such a question.

Shostakovich's Friday night speech is published in Speaking of Peace in the section entitled "Voice of the Nations" (125-26). This speech, conflated with his long panel speech, can also be found in Sovetskaya Musika (May 5, 1949). It is much briefer than his panel speech, about two columns of text in Speaking of Peace as opposed to eight and a half columns for the Saturday night speech. In the Friday session, one to two delegates from each nation gave brief remarks-America, Poland, Czechoslovakia, the USSR, Yugoslavia, Cuba, England, France, and Ireland. Shostakovich's Friday evening speech was not mentioned in Musical America (April 1), Music News (May 1949), Life (April 4), Time (April 4) or Newsweek (April 4). The Musical Courier (April 15) made only brief mention of this speech as "an appearance at a public dinner," and the New York Times gave a short summary (“Our Way Defended to 2,000 Opening 'Culture' Meeting," March 26).

This speech was fairly general in tone; Shostakovich brought greetings from "the army of Soviet musicians" and advocated unity among "progressive workers in the field of culture. ${ }^{80}$ Shostakovich's speech criticized "the new aspirants to world domination." His language, like that of the other Soviet delegates, was strongly militaristic for a peace conference: he spoke of an "army" of Soviet musicians, "fighters for peace," the "struggle for progress" (over formalism and other dark forces), the need to

\footnotetext{
${ }^{75}$ After his denunciation in 1946, Zoshchenko wrote several short stories and a play and translated two novels, but there is no evidence that he had written a novel by 1949, as Fadeyev claimed.

${ }^{76}$ Gillmor, Speaking of Peace, 86.

${ }^{77}$ For examination of the particulars, see Klefstad, "Reception," 103-51.

${ }^{78}$ Gillmor, Speaking of Peace, 87.

79 "Shostakovich Visits America for Turbulent Peace Meeting," Musical America 49 (April 1, 1949): 3-4; and "Panel

Discussions of the Cultural Conference Delegates Cover a Wide Range of Subjects," New York Times, March $27,1949$.

${ }^{80}$ Gillmor, Speaking of Peace, 125-26.
} 
"compel the warmongers to retreat," and so on. He described a veritable battle for peace, while mentioning ongoing wars in Greece, China, Palestine, Vietnam, Indonesia, and Madagascar. He closed:

May our struggle for peace, life and human dignity, our struggle against war, death and barbarism unite and strengthen our forces and serve the cause of the true rebirth and full flowering of the musical art of our times.

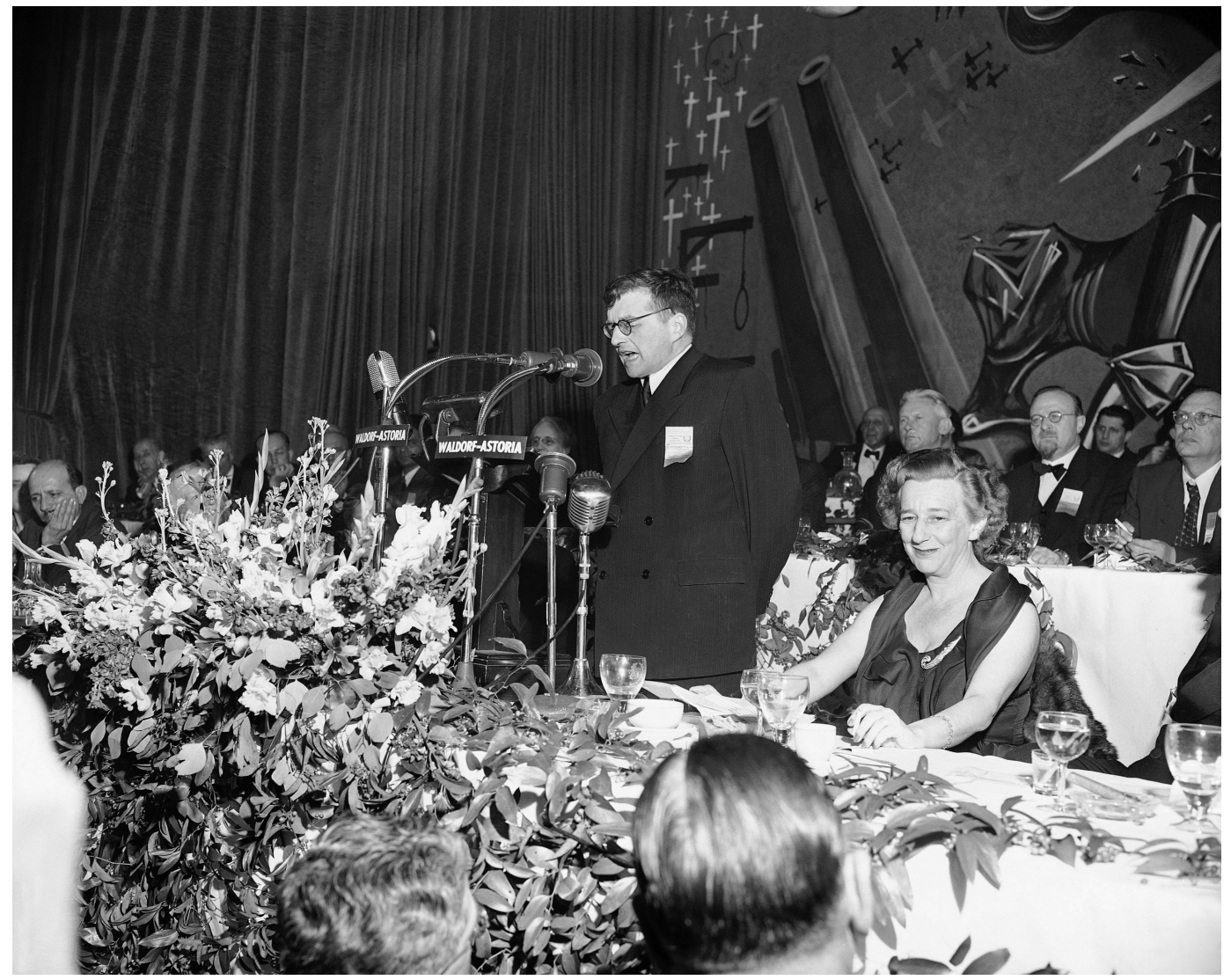

Figure 3. Shostakovich at the podium. (Associated Press photo; used with permission.)

The next day, Saturday, March 26, was reserved for the panel discussions. The panel on Fine Arts was introduced by Olin Downes, and included speeches by Philip Evergood (artist, United States), Aaron Copland, Clifford Odets (playwright, United States), Ladislav Stoll (publicist and critic, Prague), Nicolas Guilien (poet and newspaperman, Latin America), and to close, Shostakovich. Downes, in his introduction to the panel, addressed Shostakovich directly. He first asserted that music was universal and reached across national borders; for example, that the Marseillaise is about liberty whether or not one speaks French. He lauded the past of Russian music, mentioning Musorgsky, Borodin, Tchaikovsky, and Rimsky-Korsakov. He spoke admiringly of contemporary composers, listing Prokofiev, Khatchaturian, Miaskovsky, Scriabin, and Kabalevsky, pointedly omitting Shostakovich's name. Downes reminded his audience of the incredible anticipation of Shostakovich's Seventh Symphony ("Leningrad") in the United States, and the acclaim given to that work and the Eighth Symphony. Then Downes addressed Shostakovich directly, reminding the composer that he did not like the Seventh or the Eighth: "I found both of your works too long, and I strongly suspected in them the presence of a subversive influence-that of the music of Gustav Mahler." 
Downes mentioned himself being attacked by the Soviet press as "a bourgeois foe" and by the American press of writing favorably of other Soviet works. Then Downes stated that he would sit down and listen, and left the podium. ${ }^{81}$

Downes's comments could be interpreted in a number of ways-most obviously, as an insult or challenge to Shostakovich. He found it necessary to remind the composer and the audience that he did not like Shostakovich's most recent symphonies. His reviews generally said that the symphonies were too long, unoriginal, and too beholden to official Soviet policy. ${ }^{82}$ Downes consistently decried Shostakovich's acquiescence to Soviet policy, especially in the case of the Fifth, Sixth, and Seventh Symphonies, and advocated artistic freedom, an issue in the foreground at the Waldorf Conference. Three years before, Downes had published two columns on Shostakovich that grappled with the question of political influence on art. ${ }^{83}$ In them, he called for Shostakovich to become independent, to compose "great and lasting" music rather than that which fits the immediate political moment. Downes was likely trying to provoke a response from the young composer, and probably curious how he would defend himself. But Downes would be disappointed. When Shostakovich gave his speech, an interpreter read a prepared document while the composer silently observed the audience.

Shostakovich's speech followed speeches by the other Fine Arts panelists. Their speeches focused on themes of the artist's relationship to society, in terms of influence and obligations. For example, Philip Evergood asserted that an artist's work reflected the culture of his times, and Aaron Copland stated that the ongoing atmosphere of fear and suspicion in the United States could prevent an artist from creating anything. Odets claimed that an artist spoke for and with the people, a familiar socialist refrain, and Stoll cited Marx and Gorky in his call for artists to labor for the people. Shostakovich's speech was far more specific than the others of the Fine Arts Panel, giving details about the Soviet musical scene and including a lengthy analysis of realism and formalism. The word "peace" appears only twice in the 5,200-word speech.

It was widely accepted that Shostakovich himself was not the author of the speech. For a parallel example, at the Prague Music Festival in 1948, Shostakovich read a speech in this manner, according to Victor Seroff: "Instead of speaking to us as everyone expected, he read a paper which had been handed out by all Soviet Embassies six months ago and, therefore, said nothing new." 84 Nicolas Nabokov writes in his memoir, Bagazh, that Russian emigrés knew that the Soviet delegates were not "free agents": "They were tortured, innocent creatures saying things they did not mean and could not believe." ${ }^{\prime 5}$ Nabokov adds that he heard Shostakovich had been ordered to read "a paper 'prepared' for him by his KGB supervisors." Laurel Fay also addresses this question in her biography of Shostakovich:

We can be sure that the politically deficient Shostakovich was not entrusted with writing the speech delivered in his name there. That the speeches and published writings . . that touched

\footnotetext{
${ }^{81}$ Ibid., 88-89.

${ }^{82}$ For an extensive treatment of Downes's reviews of Shostakovich's symphonies as performed in America, see Klefstad,

"Reception." As the music critic for the New York Times, Downes played an important role in shaping American opinion on Soviet music.

83 "Politics vs. Art," New York Times, November 17, 1946; "Effect of an Epoch: How it Conditions a Composer's Work in Soviet Russia Examined Again,” New York Times, December 1, 1946.

${ }^{84}$ Victor Seroff, "Candid Snapshots of Musical Post-War Europe," Etude 66 (February 1948): 65-66.

${ }^{85}$ Nabokov, Bagazh, 235.
} 
even remotely on matters of state policy or image were closely monitored and regulated by appropriate levels of the Party apparatus was accepted procedure. ${ }^{86}$

Arthur Miller had similar sympathies toward Shostakovich, as he wrote in his 1987 memoir, Timebends: "But it is the memory of Shostakovich that still haunts my mind when I think of that day-what a masquerade it was!" ${ }^{\prime 7}$ The Russian League for People's Freedom issued a resolution stating that the Soviet delegates were "unable to voice their own opinions under penalty of forfeiting their lives." ${ }^{\text { }}$ Press coverage at the time of the conference, however, reported the speech as Shostakovich's own words. The speech was given fairly lengthy treatment in Musical America, Newsweek, and the New York Times and was quoted in abridged form in Music News.

The speech began by outlining the basis of Soviet thought on music, as articulated by Lenin, that it must be a "democratic art possessing great social force and required to educate the masses, to raise their cultural level, their conscience, their creative power." ${ }^{89}$ Shostakovich then described Soviet musical culture, citing "97,000 non-professional music collectives" and 1,500,000 participants in music in the R.S.F.S.R. alone. He then lauded a flowering of folk music culture in other republics, listing numbers of theatres and various new works. Shostakovich next turned to racism, denouncing it and connecting it both to Hitler and colonialism. Then Shostakovich approached the main purpose of his speech, to describe the difference between realism and formalism. His definitions were somewhat nuanced and lengthy, and contain typically harsh language for formalism: "The degeneracy and hollowness of pseudo-culture which lacks a national and popular base, the disgusting features of cosmopolitanism." Realism was defined as of and for the people, beautiful and transparent, while formalism was "nihilistic" and ignored the audience. Shostakovich used Stravinsky as an example of a formalist composer, and turned Stravinsky's own words against him: "The mass, in relation to art, is a quantitative term which has never once entered into my considerations." And "My music does not express anything realistic." Shostakovich also addressed Prokofiev's difficulties in his search for a realistic style, as he "devote(d) himself to big and significant themes." His criticism of Stravinsky and Prokofiev was one of the aspects of his speech most often reported on in the American press.

Then came what was surely the most humbling section of Shostakovich's speech. Just over a year before, Shostakovich had suffered humiliation in the form of an official pronouncement of "formalism" in his music, a ban on the performance of much of his music, and the loss of his teaching positions at the Moscow and Leningrad Conservatories. In March 1949, surely, Shostakovich was still suffering from this harsh treatment, and as mentioned above, the ban on his music was lifted only in the days immediately preceding the Waldorf Conference. In his speech, Shostakovich directly addressed the official criticism of 1948. He remarked that such criticism came from "the demands of the people." He admitted failure:

In those of my works-especially those of the post-war years-in which I departed from big themes and contemporary images, I lost my contact with the people-and I failed. My work

\footnotetext{
${ }^{86}$ Fay, Shostakovich: A Life, 173.

${ }^{87}$ Miller, Timebends, 239.

88 “Emigres Hold Fear Deters Russians," New York Times, March 28, 1949.

${ }^{89}$ Gillmor, Speaking of Peace, 95.

${ }^{90}$ Ibid., 97.

${ }^{91}$ At the time of this speech, Stravinsky had settled in Hollywood and would gain American citizenship later that year. Prokofiev, having left Russia after the Revolution, returned in 1936 to launch a career in the Soviet Union with little success.
} 
found response only among the narrow strata of sophisticated musicians-but they failed to meet with approval among the broad masses of listeners. ${ }^{92}$

Shostakovich expressed hopes that his search for "a great theme, for significant content, for more perfect and exact musical language" would be fruitful, and he pointed to the music for the film "Young Guard" (based on the novel by fellow panelist Fadeyev) as a recent success in this direction. The ending of Shostakovich's speech called for all young artists to join together in creating a progressive art with national culture and realism. This was his second apology (the first was in 1948), and his public acknowledgment that the direction of his compositional endeavors was determined wholly by the Soviet government, which demanded from him "big themes and contemporary images," a sufficiently broad description so as to allow for criticism of most compositional types and styles. Shostakovich's admission of failure to adhere to official Soviet musical policy was a widely reported element of his speech. Clearly, he was following the official line as had been predicted and reported. Musical America had predicted that Shostakovich's visit would "represent utter debasement of artistic freedom" and later reported that his speech "bore a marked resemblance to the official statement" of $1948 .{ }^{93}$ In session, United States Representative Abraham Multer of New York said that Shostakovich was "whipped into line on admittedly public grounds." 94 There was a strong sense in many accounts of the conference that Shostakovich's political duties were obligatory, and thus, not heartfelt. For example, the American Writers Association called Shostakovich "a prisoner of the Politboro"; Rabbi William F. Rosenblum called the delegates "sheep in wolves' clothing." "In Time, the American public read that Shostakovich, "a symbol of the harshness of the police state, spoke like a Communist politician and acted as though he were impelled by hidden clockwork rather than the mind which had composed resounding music." 96

Arthur Miller would later remark with compassion in his memoir: "God knows what he was thinking in that room, what splits ran across his spirit, what urge to cry out and what self-control to suppress his outcry lest he lend comfort to America and her new belligerence toward his country, the very one that was making his life a hell." ${ }^{" 97}$ Miller's comment shows a nuanced understanding of Shostakovich's position in 1949; a loyal yet beleaguered Soviet composer, struggling with how to create within a highly restrictive society. This point of view is consistent with many evaluations of Shostakovich in the American press around this time, both in concert reviews and feature articles. It shows both the rising fear of Soviet policies and an eagerness to perceive the composer as a complex human being who creates for the sake of musical expression, views not unlike those expressed by many today who enjoy Shostakovich's music. Americans in 1949 sympathized with Shostakovich because they were familiar with and liked his music (with the possible exception of Olin Downes). Elsewhere I have written about the great popularity of Shostakovich's symphonies with his American audiences, and of the mass appeal of his musical style. ${ }^{98}$ The much-publicized performances of his Seventh Symphony in 1942 and 1943 made Shostakovich much more than a composer in the eyes of Americans; he was almost a folk hero. Thus, the American public,

\footnotetext{
${ }^{92}$ Ibid., 98.

93 "Shostakovich to Speak at Conference in New York," Musical America 49 (March 1949): 3; "Shostakovich Visits America for Turbulent Peace Meeting," Musical America 49 (April 1, 1949): 3-4.

${ }^{94}$ Abraham Multer, speaking on the Cultural and Scientific Congress for World Peace, 81st Congress, 1st sess., Congressional Record 95, no. 3 (March 23, 1949): 3069.

95 “Anti-Red Session is Hailed by Tobin," New York Times, March 26, 1949; “'Cultural’ Parley is Scored by Rabbi,” New York Times, March 27, 1949.

96 "Tumult at the Waldorf," Time 53, no. 14 (April 4, 1949): 22.

${ }^{97}$ Miller, Timebends, 239.

${ }^{98}$ See Klefstad, "Reception.”
} 
fond of his music, and knowing about Shostakovich's recent troubles and the 1948 resolutions, expressed solidarity and support for the composer.

At the end of Shostakovich's lengthy speech, Nicolas Nabokov gave a tangible expression of these sentiments; he rose to his feet and asked Shostakovich two questions: (1.) Was he in agreement with the recent "bilious" attacks in the Soviet press on Paul Hindemith, Arnold Schoenberg, and Igor Stravinsky? and (2.) How can free cultural exchange exist when the USSR disallowed the performance of virtually all modern Western repertoire ? $^{99}$ In his memoir, Nabokov wrote that he asked these questions in order to expose Shostakovich's inability to respond freely. He also wrote that one Russian muttered "Provokatsya" and that Shostakovich's interpreter began whispering in his ear. ${ }^{100}$ Shostakovich responded to these provocative questions in a predictable manner: that he agreed with the criticism of modern composers, and that the best works of the West would always find a place in the Soviet repertoire. ${ }^{101}$ His answers, supportive of Soviet policy, were fully in accord with Nabokov's expectations-Nabokov did not believe these answers to be sincere. Nabokov, as an emigré, had a personal interest in exposing the lack of freedom for Soviet citizens. He saw the Waldorf Conference as an opportunity to do so, and Shostakovich, whom he admired, as the ideal representative of an oppressive society. ${ }^{102}$

The exchange with Nabokov, Miller's reactions, and the response of the American press are crucial to our understanding of the American perception of Shostakovich as a Soviet composer in 1949. The American public understood that Shostakovich had ostensibly come to New York as a propagandist, to promote the official Soviet view. But they also had experienced the very human appeal of his music and wished for his artistic freedom. No wonder that the young protester outside the Waldorf held up his sign and that the American Federation of Musicians, upon hearing that Shostakovich was coming for the Conference, invited him to apply for permanent residence. ${ }^{103}$ Thus, at a conference that consisted almost entirely of speeches and political discourse rather than cultural exchange, music played a far greater role than any might have suspected. Shostakovich's symphonies and his opera Lady Macbeth of Mtsensk District loomed over the panels like a barely noticed specter, as the composer listened to his translator read a prepared speech and mumbled brief answers to awkward questions. Indeed, the only audible musical happening of the weekend was the very end of the conference.

On the following day, Sunday, March 27, Shostakovich closed the peace conference with his piano performance of the second movement of his Fifth Symphony at Madison Square Garden (see Figure 4). The rally began at 8:00 p.m.; he performed his piece at 11:40 p.m., to resounding ovations. A highly detailed description of the rally in the New York Times notes that he was presented with a scroll of friendship, signed by forty-two musicians, including Leonard Bernstein, Aaron Copland, Serge Koussevitzky, and Eugene Ormandy. The scroll read:

\footnotetext{
${ }^{99}$ This exchange is documented in several sources: Nabokov, Bagazh; Wilson, A Life Remembered; Gillmor, Speaking of Peace.

${ }^{100}$ Nabokov, Bagazh, 237-38.

${ }^{101}$ Gillmor, Speaking of Peace, 99.

${ }^{102}$ Amy Beal writes briefly of Nabokov's role in promoting American music in post-war West Germany in New Music, New Allies: American Experimental Music in West Germany from the Zero Hour to Reunification (Berkeley: University of California Press, 2006), 13-16. Saunders, in The Cultural Cold War, describes several activities undertaken by Nabokov, especially his roles as General Secretary for the Congress for Cultural Freedom, as influenced or funded by the CIA to undermine the Soviet Union's influence on intellectuals and artists. Whether Nabokov knew the source of funding for these activities is unclear, but his activities at the Waldorf show him to be a strong advocate for artistic autonomy and a strong critic of the Soviet Union.

103 "Shostakovich to Speak," Musical America 49 (March 1949): 3.
} 
Music is an international language, and your visit will serve to symbolize the bond which music can create among all peoples. We welcome your visit also in the hope that this kind of cultural interchange can aid understanding among our peoples and thereby make possible an enduring peace. $^{104}$

Richard Parke noted that Shostakovich received the largest ovations of anyone at the rally.

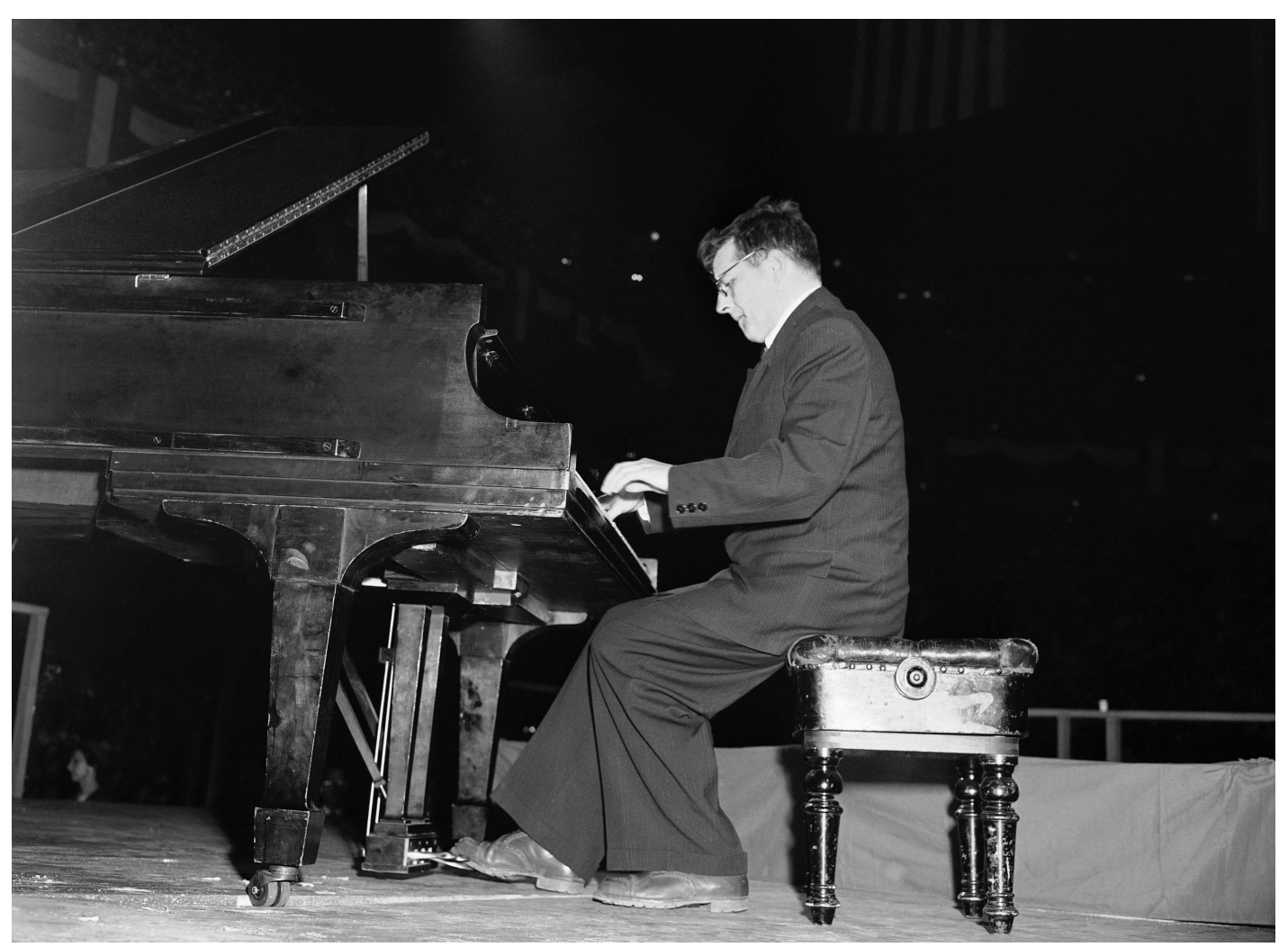

Figure 4. Shostakovich at Madison Square Gardens. (Associated Press photo; used with permission.)

Several post-conference events had been planned and announced: peace rallies in Newark and Philadelphia, and for Shostakovich, invitations to lecture and perform at Harvard, Columbia, and Juilliard. Shostakovich was able to attend a concert of Bartók String Quartets nos. 1, 4, and 6 in Times Hall on Monday, March 28. The U.S. State Department, however, on the grounds that the Soviet delegates' visas had been issued only for the purposes of the conference, asked them to leave promptly, and their visit was cut short. ${ }^{105}$ Shostakovich, carrying phonograph records and boxes of cigarettes, left with the Soviet delegation on April 3, saying only that he was "glad to return home." 106 About a week later, a notice appeared in the New York Times that Shostakovich would represent the Soviet Union at the Partisans of Peace Congress in Paris, but he did not attend that conference. ${ }^{107}$ Shostakovich had done his official duty,

104 “Global Unity Call, Cheered by 18,000, Ends Peace Rally,” New York Times, March 28, 1949.

105 "Culture Visitors Told by U.S. to End Tour and Go Home," New York Times, March 30, 1949.

106 "7 Cultural Rally Russians Depart Carrying Big Supply of Cigarettes,” New York Times, April 4, 1949.

107 “Soviet Picks Delegation,” New York Times, April 11, 1949. 
and upon his return home would compose the socialist realist oratorio Song of the Forests, Opus 81. It was quite successful, and in 1950, won a Category 1 Stalin Prize. Simultaneously, he was working on his String Quartet no. 4, which was not accepted for performance until 1953.

These two pieces further illustrate the duality of Shostakovich that was apparent during the conference: the oratorio, a public work, centering on the realistic "big themes" described in his speech at the Waldorf, and the private Fourth String Quartet, an abstract work in the formalist tradition. During Shostakovich's visit to New York, Americans sensed that duality. He was an official delegate, with a speech that was clearly Soviet official propaganda, but he was also the composer of the beloved First, Fifth, and Seventh Symphonies, and the humorous but puzzling Ninth. The mass appeal of his music, especially his socialist realist symphonies like the Fifth and the Seventh, had helped to secure a particular American fondness for the composer, even while he was suspect as an official Soviet cultural ambassador. Because of this, perhaps, Shostakovich's 1949 trip to New York served to cement the increasing belief among Americans that Shostakovich followed Soviet policy because he was obliged to do so, not because he had any great personal convictions regarding communism. After hours of speech giving, pointed questions, and pat answers, Shostakovich gave to his American audiences the very thing that had made him a popular figure-a musical performance, however brief. And they showed their gratitude to him quite plainly with their ovations and demands for repeated bows. These few minutes of shared music did what no speech could: they cemented a bond between the American audience and the Soviet composer. His music is what gained him more attention at the conference than any other delegate, and this is what made him a sympathetic figure for Americans.

A close look at Shostakovich's role in the 1949 conference as a public figure helps to illuminate the enigma that has remained part of Shostakovich's legacy to this day. Shostakovich's reputation in the English-speaking musical world has always been colored by his actions as a dutiful Soviet composer. He served as a cultural delegate in various foreign countries, returning to the U.S. in 1961 and 1973, held office in the Composers' Union, and even joined the Communist Party in 1960. In the context of the cold war, these actions meant that Shostakovich was a loyal communist, and therefore fully in support of repressive official policies. A natural reaction to Shostakovich would have been to denounce him just as they were denouncing other famous communist citizens, like Fadeyev. Americans and others, however, continued to hear something in Shostakovich's music that appealed to them and made them hope that in spite of his official duties, Shostakovich was a human being with human frailties and an individual artistic voice. Further, their awareness of repeated official persecution of Shostakovich gave them a concrete reason to be sympathetic. His music was not solely the expression of the Soviet State; it was produced by a fellow human being.

Shostakovich's presence at the Cultural and Scientific Conference for World Peace in March 1949, and the public response to it, show that Shostakovich's music, with its appeal to a wide public regardless of its politics, is essential to understanding the enigmatic nature of his public image. He stood on the world stage again and again as a Soviet composer, and many of his audiences did not believe his words (or those of his interpreter). They believed his music. This is not a postmodern construct-it was there from the rising years of his career and remains to this day. 